\title{
Formica uralensis Ruzsky (Hymenoptera: Formicidae) in Poland
}

\author{
Anna M. StanKIEWICZ*, Marcin SIELEZNIEW**, Marek L. BorowIEC*** \\ and Wojciech CZECHOWSKI*
}

\begin{abstract}
*Laboratory of Social and Myrmecophilous Insects, Museum and Institute of Zoology, Polish Academy of Sciences, Wilcza64,00-679Warsaw,Poland; e-mails:ams@miiz.waw.pl,wcz@miiz.waw.pl

**Department of Applied Entomology, SGGW-Warsaw Agriculture University, Nowoursynowska 159, 02-776 Warsaw, Poland; e-mail: sielezniew@alpha.sggw.waw.pl

***Zoological Institute, University of Wroctaw, Sienkiewicza 21, 50-335 Wroctaw; e-mail: petiolus@gmail.com
\end{abstract}

\begin{abstract}
Formica uralensis Ruzs. is a boreo-montane ant species, common to the area east of the Ural Mts, but very scarce and relict in Europe, where is occurs almost exclusively in peat bogs. In Poland, the species was known only from one site, Bagno Rakowskie, a peat bog near Frampol, the Roztocze Uplands, where it was found half a century ago. The current presence of the species there is confirmed and two new localities are reported in the Lublin Uplands: in a peat bog in the Moszne Lake nature reserve within the Polesie National Park and in a marshy meadow near the Buzornica peat bog at Kosyń within the Żółwiowe Błota nature reserve.
\end{abstract}

Key words: ants, Formica uralensis, relict species, peatland fauna, Poland

\section{INTRODUCTION}

Formica uralensis Ruzs. is a widely distributed boreo-montane species. Its northern range limit is a little south of the northern border of the forest zone, and the southern limit runs across Ukraine, the upper course of the Ural River and the Altay Mts, reaching the Pacific shores in the east. West of the Ural $F$. uralensis has been reported from isolated sites in western Russia, the Baltic states, Scandinavia (occurring rather abundantly in Sweden and Lapland; see Rosengren 1969 and Collingwood 1979), Belarus, Poland, Germany, Denmark, Switzerland and France (Pętal 1963, Dlussky 1967, Dlussky and Pisarski 1971, UNEP-WCMC 2005; see also Fig. 70 in Czechowski et al. 2002). Dlussky and Pisarski (1971) and Pisarski (1975) suggested that $F$. uralensis also occurred in the Netherlands, where extensive peat bogs existed in the past (see Mabelis and Chardon 2005), but the species was never found in that country (A. Mabelis, pers. comm.).

In the centre of its distribution area, i.e. in Asia, and particularly in the eastern part of the continent (southern Siberia, northern Mongolia), F. uralensis is eurytopic, inhabiting a variety of habitats, usually dry and open ones, especially steppe and forest-steppe, but also open forests (Dlussky 1967, Dmitrenko and Petrenko 1976, Kupyanskaya 1990, Radchenko 2005). It is actually a dominant species in some ant assemblages in the steppe (Reznikova 1983) and is rarely found in wet meadows and peat bogs. In Europe (and also across the northern border of its continuous range) this species is clearly stenotopic and occurs almost exclusively at relict sites of the pleistocoene glaciation - transitional mire and raised bogs, much less frequently on drier heath and mountain meadows. Vepsäläinen et al. (2000) classify F. uralensis among "bog specialists". The species even shows certain physiologic adaptations to living in periodically waterlogged nests (Gyllenberg and Rosengren 1984). 
For a discussion of the origins of this radical intraspecific ecological diversity in $F$. uralensis see Dlussky (1967) and Pętal (1963), and for descriptions of the mode of nesting and biology of the species see Dlussky (1967), Pętal (1963, 1964), Rosengren (1969, 1985), Dmitrenko and Petrenko (1976) and Reznikova (1983).

\section{OCCURRENCE}

The earliest finding of F. uralensis in Poland dates back from 1956 and is from the Bagno Rakowskie bog (=Błota Rakowskie) near the locality of Frampol in the Roztocze Uplands (50³8’N, 22³9’E; UTM FB11) (Fig. 1) (Pętal 1963, 1964). Bagno Rakowskie covering 618 ha (plans are under way to make it a nature reserve within the Janowskie Forest landscape park) is a near-natural forest transitional peat bog, with a raised bog-like central part; there are sparse dwarf pine and linden trees with an admixture of willow (Fig. 2). According to the report by Pętal (1963), repeated by Dlussky and Pisarski (1971), "fairly numerous" nests of $F$. uralensis were seen in a part of the peat bog exhibiting an advanced stage of plant succession, with well-developed clumps of Sphagnum spp. and Polytrichum spp., overgrown with Andromeda polifolia L. and Calluna vulgaris (L.). The nests were found in very wet clumps. The mounds, up to a dozen centimeters tall and up to approximately $30 \mathrm{~cm}$ in diameter, were built from dry pine needles, leaves of A. polifolia, Oxycoccus quadripetalus Gilib., Ledum palustre L., and remnants of grasses, sedge and mosses. The bases of nests, carved out in the peat, reached $40 \mathrm{~cm}$ below (Pętal 1963, 1964).

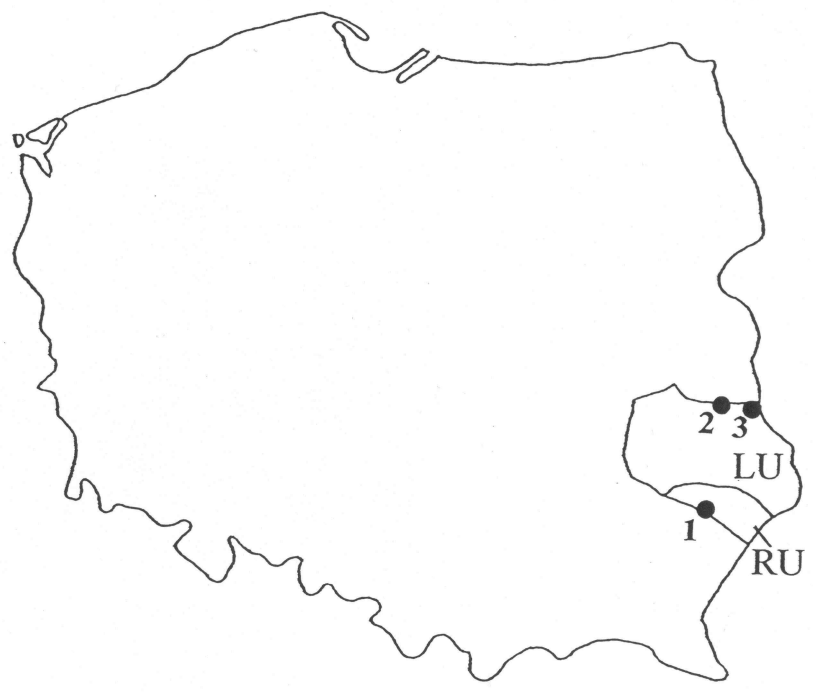

Fig. 1. Localities of F. uralensis in Poland: 1 - Bagno Rakowskie, 2 - Moszne Lake nature reserve, 3 - Żółwiowe Błota nature reserve; RU - Roztocze Uplands, LU - Lublin Uplands.

Since that first report of F. uralensis (Pętal 1963), Bagno Rakowskie has not been the site of ant research for more than 40 years, remaining the only known locality for this species in Poland until September 2005, when M. Sielezniew inspected this area, concentrating especially on the local myrmecofauna. His findings included seven nests of $F$. uralensis, all in the transitional peat bog patch with sparse forest cover, mainly of dwarf pine trees and some birch trees. The nests consisted of pine needles, dry remnants of mosses and Ledum palustre L. (Fig. 3). Some of them were surrounded by Vaccinium uliginosum L. shrubs. Nests of F. uralensis were not present in 
the open and very wet parts of the peat bog. The Imielty Ług nature reserve, the biggest peat bog area in the region, was also explored at the same time but $F$. uralensis was not found there. Probably patches that at first sight seemed to be suitable for this species because of the presence of small pine trees were in fact too dry; besides Andromeda, Oxycoccus, Vaccinium and Ledum species, some Calluna vulgaris shrubs were present in the turf.

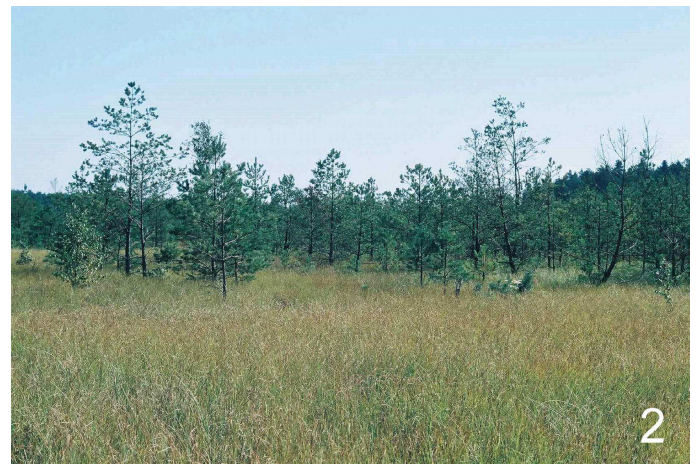

Fig. 2. Bagno Rakowskie peat bog (photo M. Sielezniew).

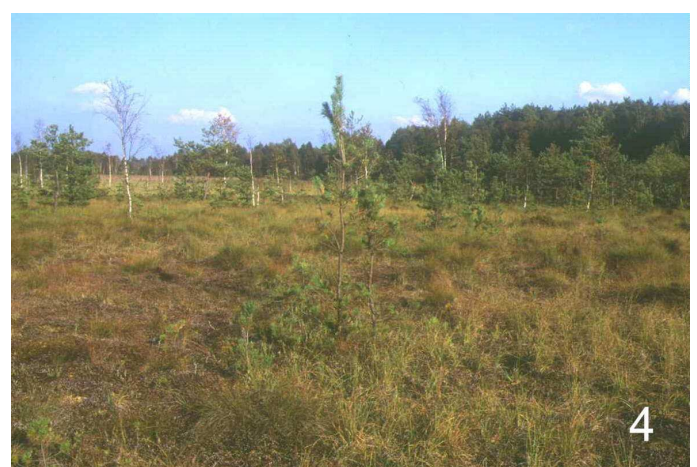

Fig. 4. Peat bog in the Moszne Lake nature reserve (photo A. M. Stankiewicz).

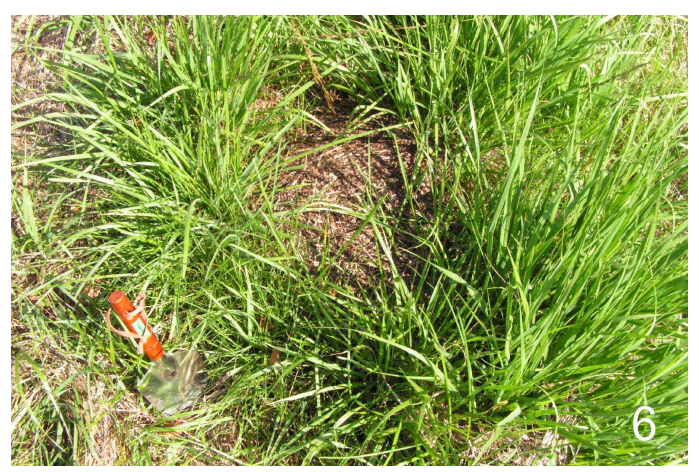

Fig. 6. F. uralensis nest in Żółwiowe Błota nature reserve (photo M. L. Borowiec).

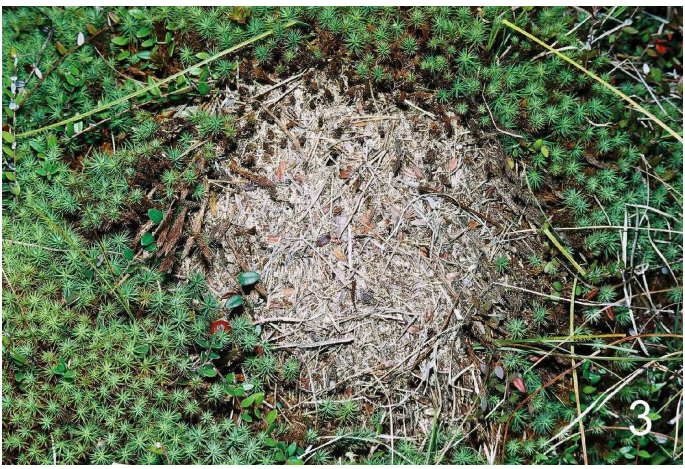

Fig. 3. F. uralensis nest in Bagno Rakowskie (photo M. Sielezniew).

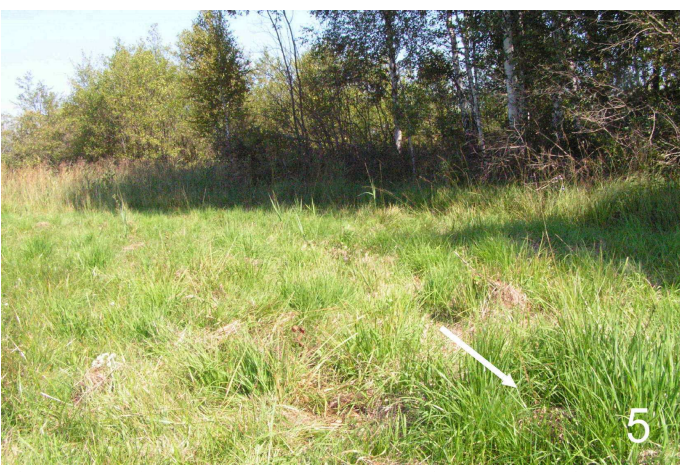

Fig. 5. Marshy meadow by the Buzornica peat bog in the Źółwiowe Błota nature reserve; situation of the $F$. uralensis nest is marked with and arrow (photo M. L. Borowiec).

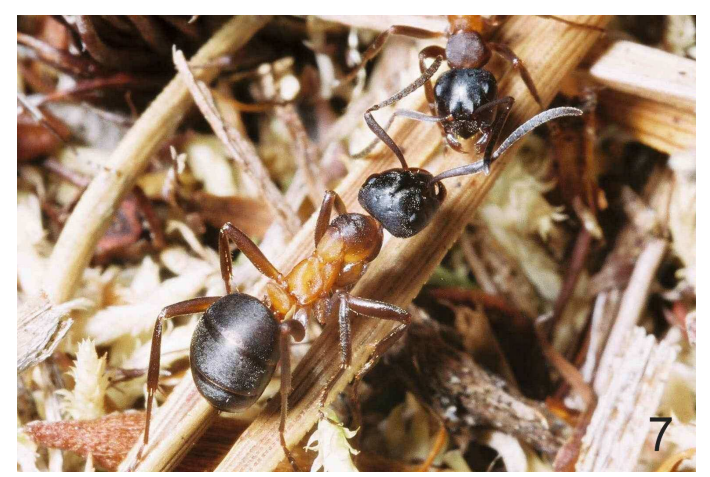

Fig. 7. F. uralensis workers (pay attention on their uniformly black heads) (photo M. Sielezniew). 
The confirmation of the presence of $F$. uralensis in Bagno Rakowskie was preceded by the discovery of two new localities of this species, both in the Lublin Uplands (Wyżyna Lubelska), which adjoins the Roztocze Uplands (Fig. 1). The first of these localities is the Moszne Lake nature reserve covering 205 ha near Wola Włoszczowska (5127'N, 2307'E; UTM FB49) within the Polesie National Park. The reserve includes a lake surrounded by a peat bog partially covered with a marshy pine forest (Fig. 4). There are rare plant species, including Betula humilis Schrk., Salix lapponum L., S. myrtilloides L., and all three domestic species of Drosera L. In the reserve, there are also some patches of transitional peat bog with small pine and birch trees. Three nests of $F$. uralensis were found there by A. M. Stankiewicz and M. Sielezniew in June 2003. The nests were made of pine needles and other dry plant material like pieces of moss and Vaccinium and Oxycoccus leaves. Besides nest samples, some workers were collected from birch trees, where ants were attending aphids.

The second new locality of $F$. uralensis, and the third one on the whole in Poland, was recorded by M. L. Borowiec in August 2005. This site is a marshy meadow close to the Buzornica peat bog within the Żółwiowe Błota nature reserve at Kosyń $\left(51^{\circ} 23^{\prime} \mathrm{N}\right.$, $23^{\circ} 33^{\prime}$ E; UTM FB79) (Fig. 5). One F. uralensis nest was found in the meadow. The nest's mound, surrounded by a ring of luxuriant grass, was about $40 \mathrm{~cm}$ wide and 15-20 $\mathrm{cm}$ high and was built mainly of fragments of grass stems (Fig. 6), which was obviously connected with the grassy habitat. More nests could possibly have been found within the peat bog itself, but the extremely high water level at the time of the inspection made it impossible to get there.

\section{DISCUSSION}

The Economic Commission for Europe (ECE 1991) classified F. uralensis into the group of insufficiently known species. The recent European Red List of endangered animals (IUCN 2004) lists it in the Lower Risk (LR) category, comprising near threatened taxa i.e. those "which do not qualify for Conservation Dependent, but which are close to qualifying for Vulnerable". However, at the edge of its distribution range, that is to say in European countries, where the species occurs on scattered relict sites, $F$. uralensis can be classified, as in Germany and Poland, as an endangered (EN) species (Blab et al. 1981, Pisarski et al. 1992, Seifert 1996, Czechowski 2002), i.e. one "facing a very high risk of extinction in the wild in the near future". In Switzerland F. uralensis is regarded as an extinct (EX) species (Cherix and Maddalena-Feller 1986). See also Day (1991).

The desiccation of peat bogs and consequently their encroachment with bushes and trees, is the main threat to peat bog species, like the one under discussion, in Europe. It is for this reason that the Polish Red Book recommends a proper management of peat bogs. It implies the maintenance of the habitat quality of $F$. uralensis, i.e. not only habitat quality within peat bogs where the species occur, but also within peat bogs at flying distance of the queens (see Mabelis and Chardon 2005). It means the counteraction of desiccation of peat bogs and the retardation of tree encroachment. In the Red Book a plea is given for a proper habitat of Rakowskie Bagno as a starting point for the protection of $F$. uralensis, but other Polish peat bogs should also be taken into account (Czechowski et al. 2004). At the same time, further searches for the species are much-desired. To aid possible searchers, here is a bit of practical advice: workers of $F$. uralensis can be distinguished from other European bicoloured Formica species by a uniformly black head (Fig. 7). 


\section{ACKNOWLEDGMENTS}

The authors thank two referees, Bram Mabelis and Alex Radchenko, for reviewing the manuscript and their suggestions and corrections, which improved the paper. A. M. Stankiewicz and M. Sielezniew are very grateful to Krzysztof Pałka for his support during studies in the Moszne Lake nature reserve.

\section{REFERENCES}

Blab J., NowaK E. \& Trautmann E. 1981. Rote Liste der gefährdeten Tiere und Pflanzen in der Bundesrepublik Deutschland. Naturschutz Aktuell. No. 1. Kilda-Verlag, Greven, 66 pp.

CheriX D. \& MAdDalenA-Feller C. 1986. Disappearance of Swiss ant species or the need for new data. In: Velthuis H. H. W. (ed.), Proceedings of the $3^{\text {rd }}$ European Congress of Entomology, Part 3, pp. 413-416. Amsterdam, $545 \mathrm{pp}$.

Collingwood C. A. 1979. The Formicidae (Hymenoptera) of Fennoscandia and Denmark. Fauna Entomol. Scand. 8, $174 \mathrm{pp}$.

CZechowsKi W. 2002. Formicidae. Mrówki. In: GŁowaciŃsKi Z. (ed.). Czerwona lista zwierząt ginących i zagrożonych w Polsce, pp. 62-65. Instytut Ochrony Przyrody PAN, Kraków, 155 pp.

CZechowski W., Radchenko A. \& CZechowska W. 2002. The ants (Hymenoptera, Formicidae) of Poland. Museum and Institute of Zoology PAS, Warszawa, $200+1 \mathrm{pp}$.

CZEChowsKi W., CZEChOWsKa W. \& RADCHENKo A. 2004. Formica uralensis Ruzsky, 1895. In: GŁOWACIŃSKI Z. \& NowACKI J. (eds), Polska Czerwona Księga Zwierząt - Bezkręgowce, pp. 200-201. Instytut Ochrony Przyrody PAN, Kraków, 447 pp.

DAY M. C. 1991. Towards the conservation of aculeate Hymenoptera in Europe. Nature and Environment Series 51. Council of Europe Press, Strasbourg, 33 pp.

DLUSSKY G. M. 1967. Murav'i roda Formika. Nauka, Moskva, 236 pp.

DLUSSKY G. M. \& PISARSKI B. 1971. Rewizja polskich gatunków mrówek (Hymenoptera: Formicidae) z rodzaju Formica L. Fragm. Faun. 16: 145-224.

DMitRenKo V. K. \& PeTREnKo E. S. 1976. Murav'i taezhnykh biocenozov Sibiri. Nauka, Novosibirsk, 220 pp.

ECE [Economic Commission for Europe] 1991. European red list of globally threathened animals and plants and recommendations on its application as adopted by the Economic Commision for Europe at its forty-sixth session (1991) by decision D (46). United Nations, New York, 154 pp.

GYLlENBERG G. \& RoSENGREN R. 1984. The oxygen consumption of submerged Formica queen (Hymenoptera, Formicidae) as related to habitat and hydrochoric transport. Ann. Ent. Fenn. 50: 76-80.

IUCN [International Union for Conservation of Nature and Natural Resources] 2004. 2004 IUCN Red List of Threatened Species. <www.redlist.org>.

KUPYANSKAYA A. N. 1990. Murav'i Dalnogo Vostoka SSSR. DVO AN SSSR, Vladivostok, 258 pp.

MABElis A. A. \& ChARDON J. P. 2005. Survival of the black bog ant (Formica transcaucasica Nasonov) in relation to the fragmentation of its habitat. J. Insect Conserv. 9: 95-108.

PĘTAL J. M. 1963. Materiały do znajomości mrówek (Formicidae, Hymenoptera) Lubelszczyzny. Fragm. Faun. 10: 463-472.

PĘTAL J. M. 1964. Fauna mrówek projektowanego rezerwatu torfowiskowego Rakowskie Bagno k. Frampola (woj. lubelskie). Ann. UMCS, ser.C 18: 143-173.

PISARSKI B. 1975. Mrówki. Formicoidea. Katalog Fauny Polski (no 23), 26, 1. PWN, Warszawa, 85 pp.

Pisarski B., Huflejt T., Garbarczyk H., GŁogowski S., Kierych E., Marczak P., Sawoniewicz J. \& SKIBIŃSKA E. 1992. Błonkówki Hymenoptera. In: GŁOWACIŃSKI Z. (ed.), Czerwona lista zwierząt ginących i zagrożonych w Polsce, pp. 43-48. ZOP \& ZN PAN, Kraków, 119 pp.

RADCHENKO A. 2005. Monographic revision of the ants (Hymenoptera: Formicidae) of North Korea. Ann. Zool. 55: $127-221$.

REZNIKOVA Zh. I. 1983. Mezhvidovye otnosheniya murav'ev. Nauka, Novosibirsk, 206 pp.

ROSENGREN R. 1969. Notes regarding the growth of a polycalic nest system in Formica uralensis Ruzsky. Notul. Ent. 49: $211-230$.

ROSENGREN R. 1985. Internest relations in polydomous Formica-colonies (Hymenoptera, Formicidae). Mitt. Dtsch. Ges. Allg. Angew. Ent. 4: 288-291.

SEIFERT B. 1996. Ameisen: beobachten, bestimmen. Naturbuch Verlag. Augsburg, 352 pp.

UNEP-WCMC [United Nations Environment Programme-World Conservation Monitoring Centre] 2005. <www.valhalla.unep-wcmc.org>.

VEPSÄLÄINEN K., SAVOLAINEN R., TIAINEN J. \& ViLÉN J. 2000. Successional changes of ant assemblages: from virgin and ditched bogs to forests. Ann. Zool. Fenn. 37: 135-149. 


\section{[Formica uralensis Ruzsky (Hymenoptera: Formicidae) w Polsce]}

Formica uralensis Ruzs. jest borealno-górskim gatunkiem mrówki, w Europie bardzo rzadkim i stenotopowym, spotykanym na rozproszonych reliktowych stanowiskach polodowcowych, niemal wyłącznie na torfowiskach. Natomiast na wschód od Uralu jest gatunkiem pospolitym i eurytopowym, najliczniej występującym na stepach i w lasostepach. W Polsce, gdzie $F$. uralensis jest uznana za gatunek silnie zagrożony, jedynym znanym dotychczas miejscem jej występowania było torfowisko Bagno Rakowskie k. Frampola na Roztoczu. Prezentowana praca przedstawia sytuację tego gatunku w Polsce: potwierdza obecność F. uralensis na Bagnie Rakowskim po blisko pół wieku od czasu pierwszego jej tam znalezienia, informuje o dwóch nowo wykrytych stanowiskach na Wyżynie Lubelskiej (na torfowisku w rezerwacie Jezioro Moszne k. Woli Włoszczowskiej oraz na podmokłej łące, przechodzącej w torfowisko Buzornica, w rezerwacie Żółwiowe Błota k. Kosynia) oraz zwraca uwagę na potrzebę działań na rzecz ochrony omawianego gatunku w kraju. 